DOI: $10.22363 / 2312-8127-2017-9-1-78-83$

\title{
ON THE QUESTION OF RADICALIZATION OF CHINA'S ISLAM IN THE WESTERN AND CHINESE HISTORIOGRAPHY ${ }^{1}$
}

\author{
E.A. Bazanova \\ Peoples' Friendship University of Russia \\ Miklukho-Maklay St., 10a, Moscow, Russia, 117198
}

In the present work, the possible approaches of China's Islam radicalization issues of Western and Chinese scholars were studied. In order to accomplish this goal, monographs and scientific articles in Chinese and English were analyzed. The works of several researchers and specialists in Islamic studies in China and Sino-Arab relations rom Great Britain, USA, Israel, Singapore and China are examined i.e. Michael Dillon (Lancaster University), Dru Gladney (Pomona Colledge), Raphael Israeli (Hebrew University), Rohan Gunaratna (Nanyang University), Li Weijiang (Shanghai University of international relations), Zhu Weilie (China's association of Middle Eastern studies), Tang Baocai (China's center of Islamic studies) etc. Based on identifying similarities and differences in viewpoints of the studied scholars, it was stated that Western researchers consider this issue as a response to violations of human rights and religious freedom by the government, while Chinese ones define it as a result of external influence and impact of international radical Islamic organizations, affiliated with local extremist groups.

Key words: Islam in China, Hui, Uighurs, Xinjiang, Radical Islam

Introduction. Many Western researchers cope with the Islamic radicalization and terrorism in China as a religious minority or political issue. Often, a conflict in China is analyzed either as a terrorism perpetrated by Uighurs in Xinjiang against China or a result of repression and excessive human rights violations by Chinese state. Frequently, scholars have also studied the issue from ethnographical or political perspectives. Such an approach is not comprehensive to reveal the root of the conflict, one of which is the threat to minority identity. There has been a little systematic examination of the interaction between the Muslim identity, global jihad, and terrorism in China. On the other side, Chinese scholars consider Islamic radicalization as a side effect of deepening of relations between China and

\footnotetext{
${ }^{1}$ Исследование выполнено при поддержке Управления по науке и инновациям Российского университета дружбы народов (инициативная НИР № 100605-0-000 «Радикальные исламские организации после «Арабской весны»: Ближний Восток, Африка, Китай»).
} 
Middle East and do not admit the local roots of this phenomenon. In their studies Chinese Muslims are clustered by their ethnicity in Uighurs and Hui who have more differences than similarities. Therefore, it is considered that Uighurs are under a great external influence and have a tendency to separatism, while Hui are loyal to Chinese government. The present work is an attempt to hold a comparison between Western and Chinese approaches for studying the Islamic Radicalization in China.

Methods \& Materials. To conduct a comparative analysis of Western and Chinese approaches, monographs and articles of specialists in Islamic studies and Sin-Arab relations i.e. M. Dillon, D. Gladney, R. Israeli, Zhu Weilie, Li Weijian, Mi Shoujiang are analyzed as relevant materials to be used as sources of information.

Research. Michael Dillon, professor in Lancaster University (UK), in his book "Xinjiang - China's Muslim Far Northwest" [2] provides essential background information of Xinjiang and a detailed analysis of the Muslim opposition against Beijing. The book is based on information collected from both of Chinese official press releases and Uighur diaspora. Dillon considers China's reaction to the disturbances and the international dimension of China's policy as an attempt to stabilize the region. However, Dillon's book has lack of theoretical analysis on the Muslim ethnicity in China. Probably it happens because there is not enough accessible information about the conflict in China especially in Xinjiang. In his another book "China's Muslim Hui minority. Migration, settlement and sects" [3] Dillon analyzes the influence of China-Arab developing relations on the Arabization of Chinese Islam. He proves that traditional Chinese Muslim culture experiences the great influence of Islamic movements from the Middle East and it faces risk to be involved in the process of purification and radicalization that can cause the tension between local Muslim communities and state government. Michael Dillon reports on deepening relations with Middle East is double-edge sword for Islam in China as it brings back Chinese Muslim community to the world "Umma", from one side and causes contradictions between adherents of traditional Chinese Islam and supporters of purification of Islam from the influence of Chinese culture from the other side[3. P. 170].

As the pioneering specialist studying Islam in China, Dru C. Gladney, president of the Pacific Basin Institute at Pomona College (USA), breaks such pattern by placing a new approach for the analysis of Muslim minorities and their confrontation with the Chinese state. In his book, "Dislocating China: Muslims, Minorities and Other Subaltern Subjects", Gladney demonstrates the ethnicity and identity of the Muslim minorities in China and their relation with the state and the majority Han Chinese. The book provides a compelling view of ethnic and religious politics that have shaped Muslim ethnicity in China. Gladney suggests three basic trends in the development of Muslim identity in China. The first trend is the growing sense of ethnic identity of Muslims in China, which he calls 
the process of "ethnicization" [4. P. 160]. The second is "transnationalization" [4. P. 4] of their ethno-religious identity caused by the "opening-up" of the country to the world and the broadened links between Muslims inside and outside China. The third is Muslim's resistance to China's policies and practice that aim at "integration" [P. 209]. According to Gladney, these factors have largely shaped the grass root conditions that sustain a "low-level" insurgency and sporadic violence in Xinjiang. However, Gladney did not pay sufficient attention to the critical role of religion in shaping that ethnic identity, which marks the division between these minorities and the Han-Chinese majority [5]. Gladney argued that the designated Uighur terrorist groups (namely ETIM and ETLO) gain "very little support for radical Islam"[4. P. 248]. Nevertheless, the fact that terrorism in China has been integrated into the global jihad movement being spearheaded by Al Qaeda and its associated and affiliated groups is clearly evidenced.

Raphael Israeli, Professor Emeritus in the Hebrew University (Israel), is specialist who made a significant contribution to study of Muslim ethnic nationalism and identity in China. In his book "Islam in China. Religion, Ethnicity, Culture, and Politics" with regard to Muslims in Xinjiang, Israeli notes that "the current revival of Islam around the world, coupled with the growing interest of the Islamic core in the minorities of the periphery, has raised the probability of Islamic renewal in these remote fringes of the Islamic world" [7. P. 1]. He examines Muslims in China not only as a "historical exoticism," but also "as a prototype of a vital Muslim minority that may be undergoing significant developments" under the influence of the changing Islamic world [7. P. 1].

The book "Ethnic Identity and National Conflict in China" by R. Gunaratna, professor in Nanyang University (Singapore), A. Acharya and Wang Pengxin emphasized on religion which has historically shaped the minority identity in China. It is Islam, and not ethnicity alone, which has shaped the Muslim identity [6. P. 7]. Moreover, Islam is now at the root of hardening of the identity that has manifested in extremism and terrorism against the state. As it was reported by the authors, the Islamist terrorist threat to China is manifestly clear and is not ambiguous [7. P. 10]. However, Beijing needs to develop an appropriate counter-terrorism posture that is transparent, legitimate, and fair to address the concerns of the international community. The book offers a theoretical framework to explain the context of ethno-religious and minorities conflicts and terrorism in general and in Xinjiang in particular. It provides a historical survey of Islam in China. A short description about the Muslim minorities in China, followed by a discussion about China's policies toward Muslim minorities is given to discuss Uighurs and East Turkistan groups that are in the forefront of terrorism and separatism in Xinjiang. Furthermore, it includes discourses on the origin and identity of Hui Muslims and their Islamic thought and the potential for radicalization and extremism in Hui community. A threat to China from transnational groups, especially Al Qaeda and its associated groups was discussed. The concluding section of the book reaffirms the link 
between threats to identity and ethnic conflicts. A hypothesis that nation-building cannot be achieved with attempts to assimilate the minorities with force, where minority identities and aspirations are sharply in contrast to those of the state was concluded.

Chinese historiography can be conditionally divided in two groups; first group includes studies of Chinese scholars on China's relations with Arabic countries of the Middle East and development of Islam in China such as "New Silk Road, fifty years of diplomatic relations between New China and Arabic states" by An Huihou [1], the specialist of China's Foreign Affairs Ministry Middle Eastern department; "Arabs' image about China" by Li Rongjiang [10], professor of Arabic Research Center in Wuhan University, "State's interests and middle eastern policy of China", by professor Li Hongjie [9], the researcher in the Center of Strategic Studies in Beijing University etc. In their studies, Chinese authors focused on historical aspects of cooperation between China and Arab countries, as well as analyze the current state of Sino-Arab cooperation in the field of politics, economy, culture, education and religion. Most of Chinese studies emphasize on the history of China and Arab countries' relationship that it is rooted in the deep past, and their development at the present stage is a kind of revival of the Great Silk Road and the establishment of civilized dialogue between the Middle and Far East Countries. In their work, they are proving that Islam appeared in China long time ago and became the part of Chinese religion system. It has its forms and traditions that were adopted and influenced by Chinese culture during the long time of interactions. Chinese Islam can be considered as a result of this long term historical process and it is a unique form of belief of most part of Chinese Muslims.

It is of a great importance for the study of Islam in China are periodicals, issued by the Chinese Association for Middle East Studies, the Institute for Middle East Studies at the Shanghai University of International Relations, Institute of West Asia and Africa, the Chinese Academy of Social Sciences, and others. Development of modern Islamic movements is studied in such journals as "Xi Ya Feizhou" ("West Asia and Africa"), "Alabo shijie yanjiu" (Arabic world studies"), Among the authors who regularly publish their articles in these journals we should mention such famous Chinese specialists in Arabic studies as Li Weijiang [11] the director of the department of West Asia and Africa studies in Shanghai University of International relations, Zhu Weile [19] - the director of the Institute of Middle East studies, vice-president of China's association of Middle Eastern researches, Tang Baocai [16] - professor in the center of China's center of Islamic studies, etc. They include an extensive factual material, which is of a great value for studying Islam in China and the specificity of interaction between Chinese Muslims and Arab world. A great attention should be given to their works that have a certain political bias and it could be noticed in focusing on the study of Islam mostly among Hui nationality and almost neglecting the problem of Islam 
in Xinjiang. In conclusion, the analyzed scholars consider Islam as a so-called bridge between China and Muslim world, which can help to develop PRC's relations with Middle East countries. However, the problem of radicalization of Chinese Islam and connections of unofficial Chinese Islamic organizations with terrorist and jihadist groups in Middle East was not discussed.

The second group devotes their works to the study of Islam in China, the role, and place of Islam in China's cooperation with the Arabic countries. In the works of Mi Shoujiang [14], Zhang Gojie [18], Ma Jiucheng [12], Ma Rong [13], Qiu Dexing [15], Li Daoxiang [8], problems of current situation of Muslim minorities, the development of Islam in China, and the role of the Chinese Muslims in China's rapprochement with the Islamic world are studied It should be noted that almost all the researchers studied the problem of China's Muslim minority, are themselves members of these nationalities. Most of the work on the subject, published in China, date back to the 1990s - 2000s. That period was not accidental because the interest of Chinese scholars regarding to that and the situation of Muslim minorities was aroused as a result of increment of the government's interest in the Islamic countries.

Conclusion. The present work introduces a reliable analysis for some suggested approaches of the controversy of radicalization of China's Islam in the western and Chinese historiography. It was established that Western scholars are focused on the problem of human rights suppression in Xinjiang and see the roots of Islamic radicalism as a result of the fight for religious freedom. On the contrary, Chinese ones consider that Islamic movements are a natural consequence of China's developing relations with Muslim world and the problem of radicalization as phenomena is not peculiar to Chinese Muslims.

(C) Bazanova E.A., 2017

\section{REFERENCES}

[1] An Huihou. Silu xinde. Xin Zhongguo he Alabo guojia wushi nian waijiao lichen. Beijing, 2006.

[2] Dillon M. Xinjiang - China's Muslim Far Northwest. London, New York, 2004.

[3] Dillon M. China's Muslim Hui minority. Migration, settlement and sects. London, 1999.

[4] Gladney D. Dislocating China: Muslims, Minorities and Other Subaltern Subjects. London, 2004.

[5] Gladney D. Muslim Chinese: ethnic nationalism in the People's Republic. New York, 1991.

[6] Gunaratna R., Acharya A., Wang Pengxin. Ethnic Identity and National Conflict in China. New York, 2010.

[7] Israeli R. Islam in China. Religion, Ethnicity, Culture, and Politics. London, 2002.

[8] Li Daoxiang. Xibu da kaifa yu xibu shehui fazhan wenti yanjiu. Beijing, 2008.

[9] Li Hongjie. Guojia liyi yu Zhongguo de Zhongdong zhengce. Beijing, 2009.

[10] Li Rongjian. Alabo de Zhonhgguo xingxiang. Beijing, 2010. 
[11] Li Weijian. The transformation of the international system and China's positive diplomacy in the Middle East // Journal of Middle Eastern and Islamic studies (in Asia). 2009. № 1.

[12] Ma Jiucheng. Huizu lishi yu wenhua yanjiu. Beijing, 2006.

[13] Ma Rong. Ethnical relations in China. Beijing, 2008.

[14] Mi Shoujiang. Islam in China. Beijing, 2004.

[15] Qiu Dexing. Xibu shaoshu minzu gaikuang. Beijing, 2008.

[16] Tang Baocai. Dui Yilake zhanzheng hou Zhongguo yu Zhongdong jingmao guanxi de sikao // Alabo shijie yanjiu. 2006. № 3.

[17] Xu Zhengui. Yisilan yu Zhongguo wenhua. Ningxia, 1995.

[18] Zhang Gojie. Bai nian zhongguo musilin. Ningxia, 2002.

[19] Zhu Weilie. Understanding and respect: on establishing a Chinese discourse system for Middle East studies // Journal of Middle Eastern and Islamic studies (in Asia). 2009. № 1. Dialogue among civilizations: a close look at the Greater Middle East reform // Journal of Middle Eastern and Islamic studies (in Asia). 2007. № 1.

\title{
К ВОПРОСУ О РАДИКАЛИЗАЦИИ ИСЛАМА В КИТАЕ В ЗАПАДНОЙ И КИТАЙСКОЙ ИСТОРИОГРАФИИ
}

\author{
Е.А. Базанова \\ Российский университет дружбы народов \\ ул. Миклухо-Маклая, 10-2, Москва, Россия, 117198
}

В данной работе были изучены возможные подходы западных и китайских ученых, касающиеся вопросов радикализации ислама в Китае. Для достижения этой цели были проанализированы монографии и научные статьи на английском и китайском языках авторов из Великобритании, США, Израиля, Сингапура и Китая. Рассматривались работы ряда исследователей и специалистов в области исламских исследований в Китае и отношений КНР со странами мусульманского мира, таких как Майкл Диллон (Университет Ланкастера), Дрю Глэдни (Помона Колледж), Рафаэль Исраэли (Еврейский Университет в Иерусалиме), Рохан Гунаратна (Университет Наньян), Ли Вэйцзян (Шанхайский университет международных отношений), Чжу Вэйле (Китайская асоциация исследований Ближнего Востока), Тан Баоцай (Китайский центр исламских исследований) и т.д. На основе выявления сходства и различия во взглядах исследователей было заявлено, что западные ученые считают процесс радикализации ислама в Китае и тенденцию образования экстремистских исламских организаций ответом на нарушения прав человека и свободы вероисповедания со стороны правительства, в то время как китайские авторы определяют его как результат внешнего воздействия и влияния международных радикальных исламских организаций, аффилированных с локальными группировками.

Ключевые слова: ислам в Китае, Хуэй, Уйгуры, Синьцзян, радикальный ислам 